\title{
臟器エキス亚に血液疾患々者血清の家兔 臟器核酸代謝に及代与影響
}

\author{
第 22 編 \\ 血液疾患々者血清の家兔歲器核酸量に及ぼす影響
}

网山大学医学部平木内科数室（主任：平木 橴数授）

難波達治

[昭和 29 年 12 月 20 日受稿]

血液疾患, 特飞或種貧血の原因に一種の毒 性物質が想定されている，例えば再生不良性:

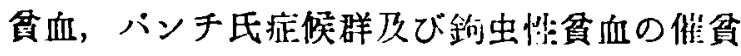
血性物質がそれである，又悪性腫瑞では催琹 液質惟物質が証明されて拉り，以上の場合所 謂毒素が抽出されている例るある。これ等の 奏駼に於ては何机も患者血清又は尿其他の作 液及び㺃器エキス，一抽出物を動物飞投与し，
その際の血液変化などをみているが、注射す る血清や尿は決して単一の成分より成るもの ではなく種々複雑な成分より成つている。乙 か子造血器は諸㮔分泌敛器と並んで最も新陳 代謝の盛な所であり，注射によつて惹起され る生体内资化は決して所謂毒素のみによる様 な単一なるのではなくて色々の変化が起され， 特に血清注射の際はその含有蛋白質の為蒙る

第 1 表 血液 疾患及者 例

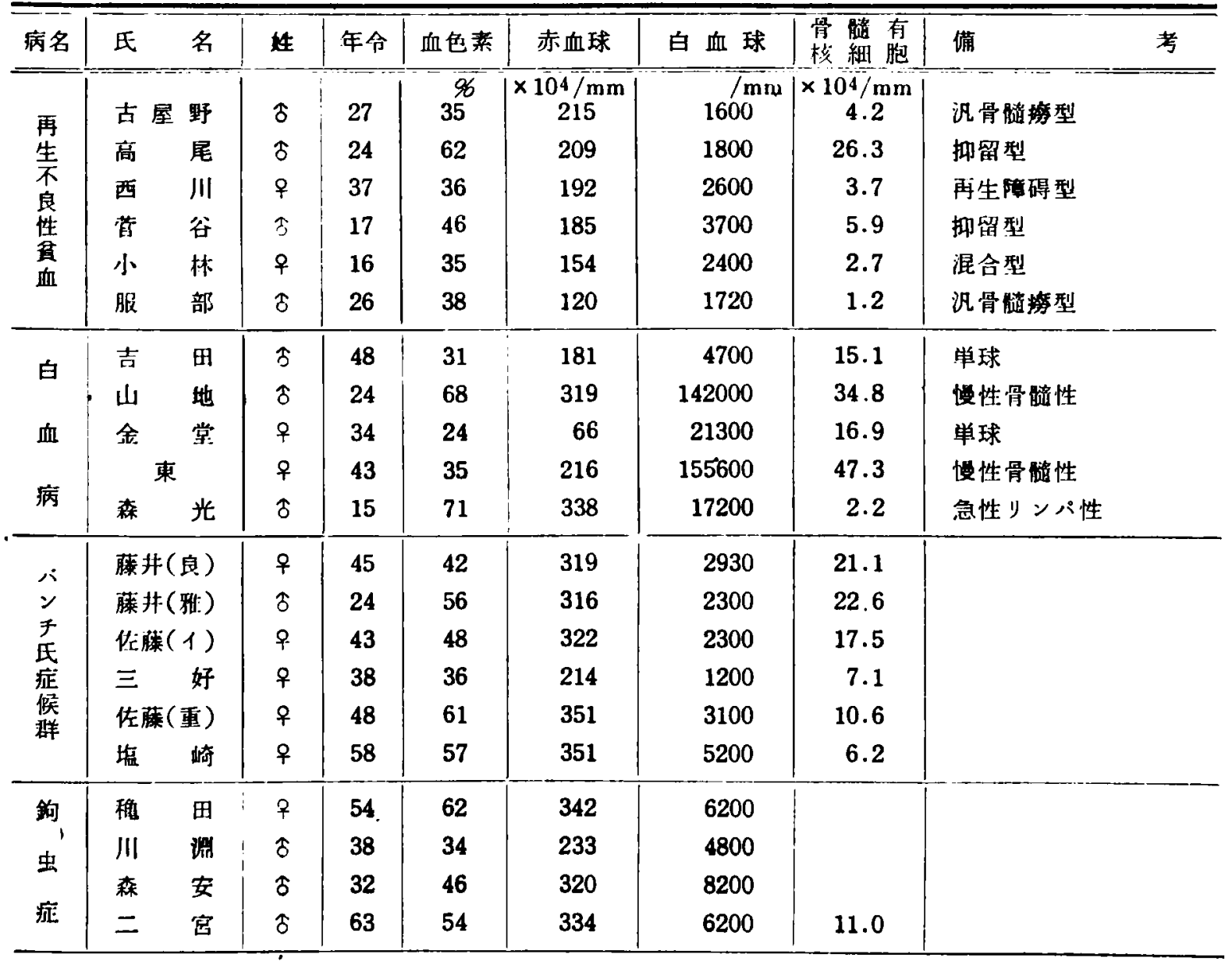


(第 1 表)

\begin{tabular}{|c|c|c|c|c|c|c|c|c|}
\hline \multirow{7}{*}{$\begin{array}{l}\text { 本 } \\
\text { 態 } \\
\text { 性 } \\
\text { 㞮 } \\
\text { 素 } \\
\text { 性 } \\
\text { 賔 } \\
\text { 血 }\end{array}$} & 岩 & 井。 & 우 & 24 & 32 & 298 & 4100 & 19.2 \\
\hline & 直 & 原 & 우 & 18 & 36 & 268 & 5700 & 5.7 \\
\hline & 佐 & 藤 & $\hat{\delta}$ & 19 & 37 & 280 & 4700 & 10.1 \\
\hline & 池 & 田 & $\hat{s}$ & 39 & 52 & 285 & 5200 & 26.2 \\
\hline & 平 & 岡 & 우 & 26 & 50 & 369 & 7700 & 23.1 \\
\hline & 吉 & 井 & 우 & 30 & 41 & 256 & 7000 & 49.9 \\
\hline & 藤 & 原. & 오 & 38 & 38 & 308 & 5600 & 11.3 \\
\hline
\end{tabular}

変化は非常に多岐に互るすのと想像される. しかるにこの際の物質代謝について研究した るのはまことに䆣々たるもので，断片的研桨

装兒するに過ぎない，勿論核酸代謝につい て論及したものはない。私は前編に引続き血 液疾患々者血清注射の際の家嵬膊器核酸代謝 を検討したのでここに報告する。

\section{§1. 実釦材料並に実験力法}

\section{1. 実験材料}

1）実驞動物 体重 $2 \mathrm{~kg}$ 削後の家鬼を使用 した.

2)、患者血清（表 1)・精密な榆直により 診断の確定した再生不良惟蚠血 6 例，白血游 5 例，バンチ氏柾候群 6 例，站们尘性貧血 4 例

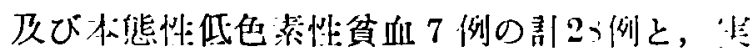

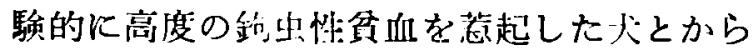
無菌的に得た血清を倠用した。对照としては 垏康人 5 例の血清を用いた。

\section{2. 実験方法}

1）注射法 早朝空腹時家鬼耳影脈に，血 清を每作重 $\lg 2$ 心㱜 1 月1 回注射した。

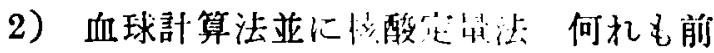
編に記したと同样。

\section{§2. 实豎 成 績}

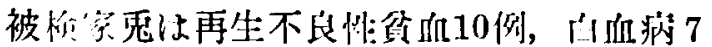
例，ハンチ氏症候群 8 例，㡖出症13例（今价

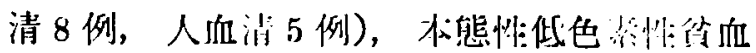
9 例, 蜮康人 5 例，部52例である。

\section{1. 赤血球数（図 1 )}

揵康人血清の際汇殆ど変動がみられない他 はすへて減少の傾向にある，即ち本態临低色 素恻貧血は增減区々であるが減少の傾向があ

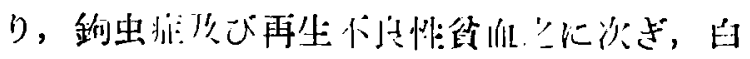

血癖並にハンチ氏症候群は甚だしい隇少を示 す.

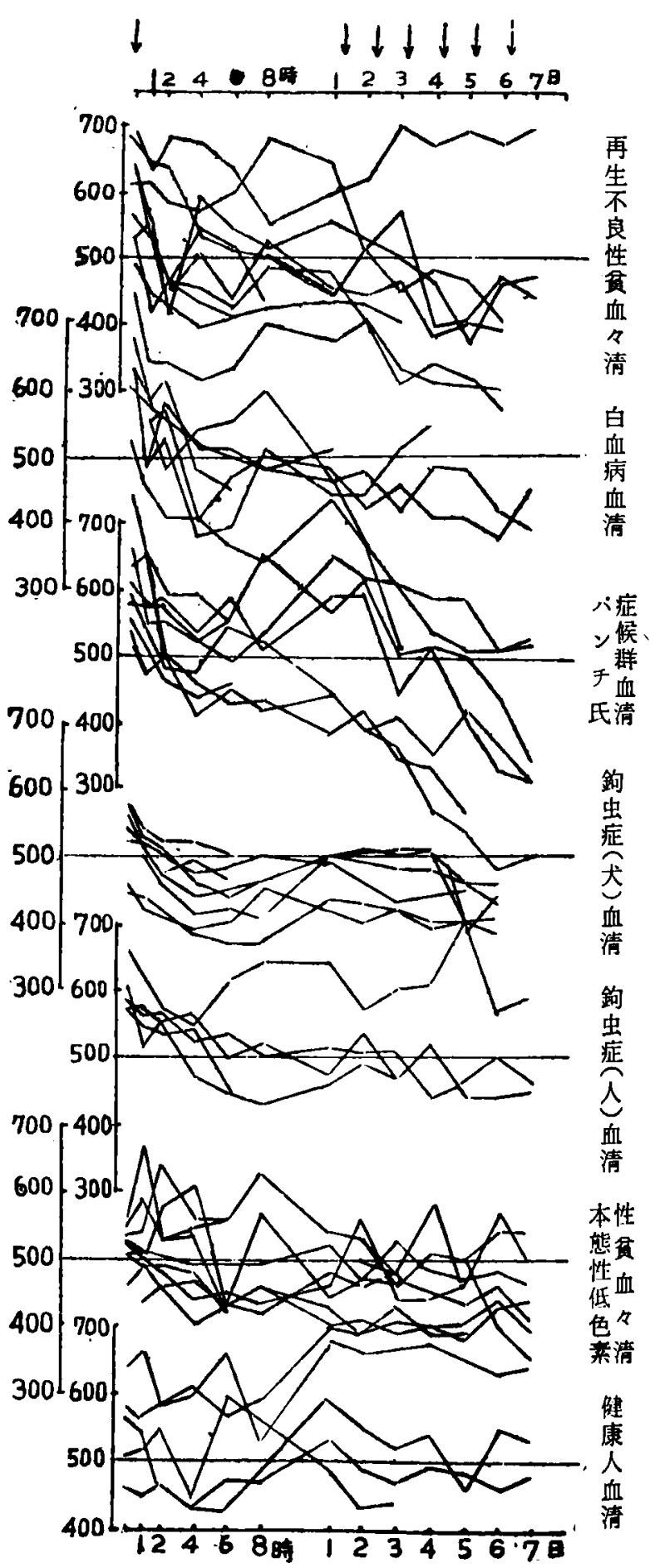

因 1. 血清注射飞よる家兔赤血球数の变動. 
2. 核酸量（表 $2 \sim 8$, 図 2)

測定した核酸量は表っ〜8 亿表示し，との 平均值を図 2 亿挙げた。数值の単位は前編に 用いたと同様である。血清注射の際は臟器工
キスに比べて增隇が著明である。

1）骨䯣核酸

骨髄核酸には翌化が多い: 验虫症（人）群 で軽度の DNA の增加と RNA の隇少とをみ

第 2 表 再生不良性貧血々清投与家鬼臓器核酸量

\begin{tabular}{|c|c|c|c|c|c|c|c|c|c|c|c|}
\hline \multirow{2}{*}{\multicolumn{2}{|c|}{$\frac{\text { 家鬼番号 }}{\text { 患者氏名 }}$}} & 0601 & 0602 & 0603 & 0604 & 0605 & 0606 & 0607 & 0608 & 0609 & 0610 \\
\hline & & 古屋野 & 高＼cjkstart尾 & 古屋野 & 西 川 & 西 川 & 菅 谷 & 小 林 & 小 林 & 高＼cjkstart尾 & 服 部 \\
\hline \multicolumn{2}{|c|}{ 注射 回 数 } & 1 & 1 & 6 & 6 & 6 & 6 & 7 & 7 & 7 & 14 \\
\hline \multicolumn{2}{|c|}{ 操 作 期 間 } & 1 & 1 & 6 & 6 & 6 & 6 & 7 & 7 & 7 & 14 \\
\hline \multicolumn{2}{|c|}{$\begin{array}{l}\text { 赤血球最大 } \\
\text { 增 減 } \\
\end{array}$} & -21.3 & -18.3 & -49.4 & -30.7 & -40.3 & -34.5 & -30.9 & -20.3 & -43.0 & -20.7 \\
\hline $\begin{array}{l}\text { 骨 } \\
\text { 䯣 } \\
\text { 核 } \\
\text { 酸 }\end{array}$ & $\begin{array}{l}\text { DNA } \\
\text { RNA } \\
\text { NA } \\
\text { R/D }\end{array}$ & $\begin{array}{r}118.4 \\
60.8 \\
161.8 \\
0.60\end{array}$ & $\begin{array}{c}37.4 \\
31.2 \\
68.6 \\
0.83\end{array}$ & $\begin{array}{r}101.0 \\
74.8 \\
193.2^{\prime} \\
0.63\end{array}$ & $\begin{array}{r}100.8 \\
60.7 \\
161.5 \\
0.60\end{array}$ & $\begin{array}{r}106.4 \\
74.4 \\
180.8 \\
0.70\end{array}$ & $\begin{array}{r}57.8 \\
49.3 \\
107.1 \\
0.85\end{array}$ & $\begin{array}{r}131.8 \\
70.7 \\
202.5 \\
0.54\end{array}$ & $\begin{array}{c}60.7 \\
27.5 \\
88.2 \\
0.45\end{array}$ & $\begin{array}{c}58.4 \\
60.4 \\
118.0 \\
1.03\end{array}$ & $\begin{array}{r}76.4 \\
44.5 \\
120.9 \\
0.58\end{array}$ \\
\hline $\begin{array}{l}\text { 肝 } \\
\text { 核 } \\
\text { 酸 }\end{array}$ & $\begin{array}{l}\text { DNA } \\
\text { RNA } \\
\text { NA } \\
\text { R/D }\end{array}$ & $\begin{array}{r}48.6 \\
68.9 \\
117.5 \\
1.42\end{array}$ & $\begin{array}{c}15.1 \\
56.3 \\
71.4 \\
3.73\end{array}$ & $\begin{array}{r}77.0 \\
107.6 \\
184.6 \\
1.40\end{array}$ & $\begin{array}{r}51.7 \\
61.7 \\
113.4 \\
1.19\end{array}$ & $\begin{array}{r}41.0 \\
93.2 \\
134.2 \\
2.27\end{array}$ & $\begin{array}{r}33.6 \\
105.9 \\
139.5 \\
3.15\end{array}$ & $\begin{array}{r}31.8 \\
153.1 \\
184.9 \\
4.82\end{array}$ & $\begin{array}{r}24.2 \\
88.0 \\
112.2 \\
3.64\end{array}$ & $\begin{array}{c}23.2 \\
52.9 \\
76.1 \\
2.28\end{array}$ & $\begin{array}{r}22.3 \\
102.0 \\
124.3 \\
4.57\end{array}$ \\
\hline $\begin{array}{l}\text { 脾 } \\
\text { 柆 } \\
\text { 酸 }\end{array}$ & $\begin{array}{l}\text { DNA } \\
\text { RNA } \\
\text { NA } \\
\text { R/D }\end{array}$ & $\begin{array}{r}61.5 \\
66.4 \\
127.9 \\
1.08\end{array}$ & $\begin{array}{r}76.0 \\
60.4 \\
136.4 \\
0.79\end{array}$ & $\begin{array}{c}114.1 \\
83.5 \\
197.6 \\
0.73\end{array}$ & $\begin{array}{r}84.9 \\
68.9 \\
153.8 \\
0.81\end{array}$ & $\begin{array}{r}76.8 \\
61.2 \\
138.0 \\
0.80\end{array}$ & $\begin{array}{r}64.0 \\
57.5 \\
121.5 \\
0.90\end{array}$ & $\begin{array}{r}142.0 \\
82.2 \\
224.2 \\
0.58\end{array}$ & $\begin{array}{r}85.5 \\
61.7 \\
147.2 \\
0.72\end{array}$ & $\begin{array}{r}73.9 \\
76.6 \\
150.5 \\
1.04\end{array}$ & $\begin{array}{r}93.1 \\
79.1 \\
172.2 \\
0.85\end{array}$ \\
\hline $\begin{array}{l}\text { 辇 } \\
\text { 核 } \\
\text { 酸 }\end{array}$ & $\begin{array}{l}\text { DNA } \\
\text { RNA } \\
\text { NA } \\
\text { R/D }\end{array}$ & $\begin{array}{c}50.4 \\
47.4 \\
97.8 \\
0.94\end{array}$ & $\begin{array}{c}35.2 \\
52.8 \\
88.0 \\
1.50\end{array}$ & $\begin{array}{r}56.5 \\
63.2 \\
119.7 \\
1.12\end{array}$ & $\begin{array}{c}64.9 \\
33.3 \\
98.2 \\
0.51\end{array}$ & $\begin{array}{c}42.0 \\
54.1 \\
96.1 \\
1.29\end{array}$ & $\begin{array}{c}42.4 \\
52.9 \\
95.3 \\
1.25\end{array}$ & $\begin{array}{c}45.1 \\
52.7 \\
97.8 \\
1.17\end{array}$ & $\begin{array}{c}39.3 \\
48.6 \\
87.9 \\
1.24\end{array}$ & $\begin{array}{c}25.2 \\
63.4 \\
88.6 \\
2.52\end{array}$ & $\begin{array}{c}29.0 \\
63.3 \\
92.3 \\
2.18\end{array}$ \\
\hline
\end{tabular}

第 3 表 白血病血清投与家鬼缄哭核酸量

\begin{tabular}{|c|c|c|c|c|c|c|c|c|}
\hline & 鬼 番 号 & 0701 & 0702 & 0.703 & 0704 & 0705 & 0706 & 0707 \\
\hline 患 & 者氏 名 & 吉 田 & 山 & 山 & 吉 田 & 金 堂 & 東 & 森 光 \\
\hline & 射 回 数 & 1 & 2 & 3 & 4 & 7 & 7 & 7 \\
\hline & 作 期 間 & 6 時 & 2 日 & 3 & 4 & 7 & 7 & 7 \\
\hline & 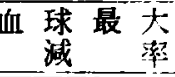 & -33.5 & -24.0 & -66.1 & -38.3 & -65.9 & -40.5 & -27.8 \\
\hline 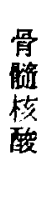 & $\begin{array}{l}\text { DNA } \\
\text { RNA } \\
\text { NA } \\
\text { R/D }\end{array}$ & $\begin{array}{c}54.4 \\
32.8 \\
87.2 \\
0.60\end{array}$ & $\begin{array}{c}41.7 \\
12.2 \\
53.9 \\
0.30\end{array}$ & $\begin{array}{r}53.8 \\
46.3 \\
100.1 \\
0.81\end{array}$ & $\begin{array}{r}75.2 \\
36.7 \\
111.9 \\
0.49\end{array}$ & $\begin{array}{r}62.6 \\
43.9 \\
106.5 \\
0.70\end{array}$ & $\begin{array}{c}52.7 \\
39.2 \\
91.9 \\
0.74\end{array}$ & $\begin{array}{r}106.4 \\
69.7 \\
176.1 \\
0.65\end{array}$ \\
\hline $\begin{array}{l}\text { 肝 } \\
\text { 核 } \\
\text { 酸 }\end{array}$ & $\begin{array}{l}\text { DNA } \\
\text { RNA } \\
\text { NA } \\
\text { R/D }\end{array}$ & $\begin{array}{c}39.8 \\
78.1 \\
117.9 \\
1.97\end{array}$ & $\begin{array}{c}15.6 \\
64.1 \\
79.7 \\
4.11\end{array}$ & $\begin{array}{c}20.8 \\
77.0 \\
97.8 \\
3.70\end{array}$ & $\begin{array}{r}33.7 \\
75.4 \\
109.1 \\
2.24\end{array}$ & $\begin{array}{c}65.6 \\
98.9 \\
164.5 \\
1.51\end{array}$ & $\begin{array}{r}45.7 \\
95.0 \\
140.7 \\
2.08\end{array}$ & $\begin{array}{c}13.9 \\
98.4 \\
112.3 \\
7.07\end{array}$ \\
\hline
\end{tabular}




\begin{tabular}{|c|c|c|c|c|c|c|c|c|}
\hline \multirow{4}{*}{$\begin{array}{l}\text { 脾 } \\
\text { 祊 } \\
\text { 酸 }\end{array}$} & DNA & 96.5 & 83.4 & 105.3 & 97.0 & 110.5 & 84.4 & 84.0 \\
\hline & RNA & 50.2 & 85.0 & 53.6 & 72.1 & 72.0 & 68.1 & 82.7 \\
\hline & NA & 146.7 & 168.4 & 158.9 & 169.1 & 182.5 & 152.5 & $1 f, 6.7$ \\
\hline & $\mathrm{R} / \mathrm{D}$ & 0.52 & 1.02 & 0.51 & 0.74 & 0.65 & 0.81 & 0.98 \\
\hline \multirow{4}{*}{$\begin{array}{l}\text { 腎 } \\
\text { 㮞 } \\
\text { 酸 }\end{array}$} & DNA & 52.5 & 29.9 & 19.6 & 42.1 & 36.7 & $40 . Q$ & 32.7 \\
\hline & RNA & 44.5 & 57.0 & 32.8 & 46.7 & 54.7 & 50.2 & 66.8 \\
\hline & NA & 97.0 & 86.9 & 52.4 & 88.8 & 91.4 & 90.2 & 99.5 \\
\hline & $\mathrm{R} / \mathrm{D}$ & 0.85 & 1.91 & 1.67 & 1.11 & 1.49 & 1.25 & 2.04 \\
\hline
\end{tabular}

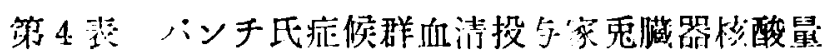

\begin{tabular}{|c|c|c|c|c|c|c|c|c|c|}
\hline \multirow{2}{*}{\multicolumn{2}{|c|}{$\frac{\text { 寄恶番号 }}{\text { 患者氏名 }}$}} & 0801 & 0802 & 0803 & 0804 & 0805 & 0806 & 0807 & 0808 \\
\hline & & 藤讲（良） & 滕讲(倠) & 滕井（雅） & 滕井(住) & 作䓦 & $\equiv$ & 佐＼cjkstart藤 & 塩 \\
\hline \multicolumn{2}{|c|}{ 注射回数 } & 1 & 1 & 5 & 7 & 7 & 7 & 7 & 7 \\
\hline \multicolumn{2}{|c|}{ 操 作 期 間 } & 1 日 & 1 & 5 & 7 & 7 & 7 & 7 & 7 \\
\hline \multicolumn{2}{|c|}{ 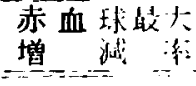 } & -19.3 & -55.3 & -58.5 & -69.6 & -41.1 & -46.0 & -26.4 & -43.5 \\
\hline \multirow{4}{*}{$\begin{array}{l}\text { 骨 } \\
\text { 能 } \\
\text { 松 } \\
\text { 酸 }\end{array}$} & DNA & 67.3 & 79.2 & 116.8 & 143.1 & 101.2 & 131.0 & 61.0 & 65.5 \\
\hline & RNA & 42.5 & 32.1 & 81.1 & 97.2 & 59.1 & 87.3 & 50.7 & 54.6 \\
\hline & $\mathbf{N A}$ & 109.8 & 111.3 & 197.9 & 240.3 & 160.3 & 218.3 & 111.7 & 120.1 \\
\hline & $\mathrm{R} / \mathrm{D}$ & 0.63 & 0.41 & 0.70 & 0.68 & 0.58 & 0.62 & 0.83 & 0.83 \\
\hline & DNA & 40.1 & 16.2 & 27.9 & 35.7 & 25.6 & 29.5 & 23.4 & 43.4 \\
\hline & RNA & 109.1 & 65.5 & 106.4 & 104.9 & 102.6 & 96.3 & 56.5 & 76.3 \\
\hline & $\mathrm{NA}$ & 149.2 & 81.7 & 134.3 & 140.6 & 128.2 & 125.8 & 79.9 & 119.7 \\
\hline & $R / D$ & 2.72 & 4.04 & 3.82 & 2.94 & 4.01 & 3.06 & 2.42 & 1.76 \\
\hline \multirow{2}{*}{ 脾 } & DNA & 76.3 & 93.7 & 74.7 & 87.7 & 94.4 & 127.5 & 95.4 & 66.7 \\
\hline & RNA & 47.3 & 47.4 & 70.0 & 74.0 & 68.2 & 77.2 & 76.0 & 76.4 \\
\hline \multirow{2}{*}{$\begin{array}{l}\text { 松 } \\
\text { 酸 }\end{array}$} & $\mathrm{NA}$ & 123.6 & 141.1 & 144.7 & 161.7 & 162.6 & 204.7 & 171.4 & 143.1 \\
\hline & $\mathrm{R} / \mathrm{D}$ & 0.62 & 0.51 & 0.94 & 0.84 & 0.72 & 0.61 & 0.80 & 1.14 \\
\hline \multirow{2}{*}{ 照 } & DNA & 31.9 & 41.7 & 38.7 & 23.9 & 32.5 & 40.6 & 39.5 & 38.9 \\
\hline & RNA & 58.6 & 56.3 & 44.4 & 62.9 & 48.4 & 51.6 & 53.1 & 62.6 \\
\hline \multirow{2}{*}{ 酸 } & $\mathrm{NA}$ & 90.8 & 98.0 & 83.1 & 86.4 & 80.9 & 92.2 & 93.0 & 101.5 \\
\hline & $\mathrm{R} / \mathrm{D}$ & 1.85 & 1.35 & 1.15 & 2.61 & 1.49 & 1.27 & 1.33 & 1.61 \\
\hline
\end{tabular}

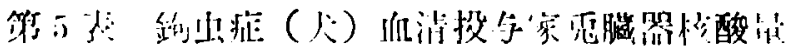

\begin{tabular}{|c|c|c|c|c|c|c|c|c|c|}
\hline \multicolumn{2}{|c|}{ 縈死番行！ } & 0901 & 0902 & 0903 & 0904 & 0905 & 0906 & 0907 & 0908 \\
\hline \multicolumn{2}{|c|}{ 汪射们数 } & 1 & 1 & 5 & 6 & 6 & 6 & 6 & 6 \\
\hline \multicolumn{2}{|c|}{ 探作期間 } & 6 時 & 6 & 5 日 & 6 & 6 & 6 & 6 & 6 \\
\hline \multicolumn{2}{|c|}{ 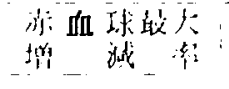 } & -13.4 & -14.6 & -14.4 & -16.7 & -31.3 & -19.4 & -16.8 & -24.0 \\
\hline \multirow{4}{*}{$\begin{array}{l}\text { 骨 } \\
\text { 咀 } \\
\text { 核 } \\
\text { 酸 }\end{array}$} & DNA & 78.5 & 94.1 & 106.8 & 70.1 & 38.9 & 53.9 & 74.1 & 71.9 \\
\hline & RNA & 40.0 & 39.6 & 41.8 & 37.9 & 18.9 & 33.8 & 59.8 & 42.0 \\
\hline & $N A$ & 118.5 & 133.7 & 148.6 & 108.0 & 57.8 & 87.7 & 133.9 & 113.9 \\
\hline & $R / D$ & 0.51 & 0.42 & 0.39 & 0.54 & 0.49 & 0.63 & 0.81 & 0.59 \\
\hline
\end{tabular}




\begin{tabular}{|c|c|c|c|c|c|c|c|c|c|}
\hline \multirow{4}{*}{$\begin{array}{l}\text { 肝 } \\
\text { 核 } \\
\text { 酸 }\end{array}$} & DNA & 59.4 & 19.5 & 51.0 & 49.5 & 37.5 & 25.9 & 19.9 & 26.3 \\
\hline & RNA & 60.0 & 102.8 & 89.0 & 61.9 & 96.3 & 125.8 & 93.2 & 78.7 \\
\hline & NA & 119.4 & 122.3 & 140.0 & 111.4 & 133.8 & 151.7 & 113.1 & 105.0 \\
\hline & $\mathrm{R} / \mathrm{D}$ & 1.01 & 5.27 & 1.75 & 1.25 & -2.57 & 4.86 & 4.68 & 2.90 \\
\hline \multirow{4}{*}{$\begin{array}{l}\text { 脾 } \\
\text { 核 } \\
\text { 酸 }\end{array}$} & DNA & 94.4 & 100.5 & 142.7 & 108.8 & 126.3 & 129.6 & 102.7 & 119.7 \\
\hline & RNA & 63.8 & 71.8 & 118.7 & 106.9 & 74.0 & 95.2 & 88.6 & 88.3 \\
\hline & NA & 158.2 & 172.3 & 261.4 & 215.7 & 200.3 & 224.8 & 191.3 & 208.0 \\
\hline & $R / D$ & 0.68 & 0.71 & 0.83 & 0.98 & 0.59 & 0.73 & 0.95 & 0.74 \\
\hline \multirow{4}{*}{$\begin{array}{l}\text { 繁 } \\
\text { 恔 } \\
\text { 醇 }\end{array}$} & DNA & 31.0 & 38.6 & 40.9 & 32.9 & 21.8 & 28.9 & 45.0 & 63.9 \\
\hline & RNA & 55.6 & 62.5 & 58.4 & 32.0 & 57.4 & 53.7 & 53.7 & 40.2 \\
\hline & NA & 86.6 & 101.1 & 99.3 & 64.9 & 79.2 & 82.6 & 98.1 & 104.1 \\
\hline & $R / D$ & 1.80 & 1.62 & 1.43 & 1.00 & 2.63 & 1.86 & 1.19 & 0.63 \\
\hline
\end{tabular}

第 6 表 鈎虫症（人）血清投与 家鬼䑏器核酸星

\begin{tabular}{|c|c|c|c|c|c|c|}
\hline \multicolumn{2}{|c|}{ 家鬼番 号 } & 1001 & 1002 & 1003 & 1004 & 1005 \\
\hline \multicolumn{2}{|c|}{ 患者氏名 } & 䅖田 & 川淵 & 稳田 & 管安 & 二宮 \\
\hline \multicolumn{2}{|c|}{ 注射 期 間 } & 1 & 3 & 7 & 7 & 7 \\
\hline \multicolumn{2}{|c|}{ 探 作 期 間 } & 6 時 & 3 & 7 & 7 & 7 \\
\hline \multicolumn{2}{|c|}{ 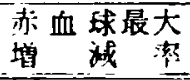 } & -2 & 1 & & -14.6 & -6.9 \\
\hline \multirow{4}{*}{$\begin{array}{l}\text { 骨 } \\
\text { 楼 } \\
\text { 核 } \\
\text { 酸 }\end{array}$} & DNA & 71.6 & 93.5 & 81.9 & 57.9 & 88.4 \\
\hline & $\mathrm{RNA}$ & 33.8 & 47.2 & 45.9 & 38.3 & 45.2 \\
\hline & NA & 105.4 & 140.7 & 127.8 & 96.2 & 133.6 \\
\hline & $\mathrm{R} / \mathrm{D}$ & 0.47 & 0.51 & 0.56 & 0.66 & 0.51 \\
\hline \multirow{4}{*}{$\begin{array}{l}\text { 肝 } \\
\text { 核 } \\
\text { 酸 }\end{array}$} & DNA & 31.1 & 35.1 & 28.1 & 32.4 & 23.7 \\
\hline & RNA & 96.4 & 77.9 & 130.7 & 86.2 & 113.4 \\
\hline & NA & 127.5 & 113.0 & 158.8 & 118.6 & 137.1 \\
\hline & $\mathrm{R} / \mathrm{D}$ & 3.10 & 2.22 & 4.65 & 2.66 & 4.79 \\
\hline \multirow{4}{*}{$\begin{array}{l}\text { 脾 } \\
\text { 核 } \\
\text { 酸 }\end{array}$} & DNA & 76.4 & 119.5 & \multicolumn{2}{|c|}{111.4117 .9} & 89.7 \\
\hline & RNA & 53.4 & 69.6 & 92.0 & 94.3 & 87.7 \\
\hline & NA & 129.8 & 189.1 & 203.4 & 212.2 & 177.4 \\
\hline & $R / D$ & 0.70 & 0.58 & 0.83 & 0.80 & 0.98 \\
\hline \multirow{4}{*}{$\begin{array}{l}\text { 等 } \\
\text { 核 } \\
\text { 酸 }\end{array}$} & DNA & .7 & 37.0 & 24.4 & 37.8 & 41.0 \\
\hline & RNA & 53.8 & 50.3 & 51.6 & 60.4 & 59.6 \\
\hline & NA & 91.5 & 87.3 & 76.0 & 98.2 & 100.6 \\
\hline & $\mathbf{R} / \mathbf{D}$ & 1.43 & 1.36 & 2.10 & 1.60 & 1.45 \\
\hline
\end{tabular}

る以外は, 何れるDNA とRNA とは步調を 一にしている，バンチ氏泟候群の增加は非常 そ著明であるが，再生不良性盆血及び本望扩 低色素性贫血でも相当量の增加がるる， 白血病群は诚少する。しかも继康人群でも白

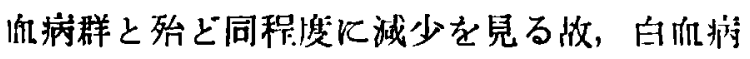

以外はすべて增吅するものと考えられる。

\section{2) 肝核酸}

DNA はバンチ氏症候群，鈎出症（人），健 康人の各挷で減少与る他. 一般飞減少の傾间 がある，RNA は鈎出症（人），本態性低色䕀 性貧血项び健康人の各群で增版している，硉 康人群を䒫淢としてみるときは，DNA は再 生不良性盆血灭び鈎虫拝（犬）の各群飞增

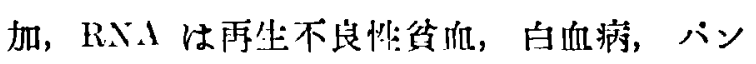
于氏症候群及び鵒出症（犬）の各群飞增加す る.

\section{3）牌核酸}

DNA は再生不良性分血，パンチ症候群 队び健康人の份样で減少し，其他も減少の傾

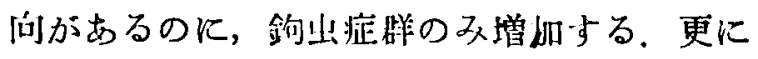
鈎山症样では RNA が著盯に增师しており他 群と著しい州问去みる。其他の RNA は侢生

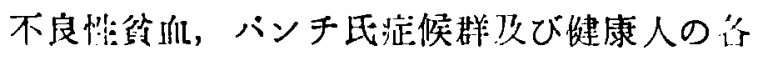
群飞轻害の減少がある。件康人群を基準とす れば DNAは白血病攻び絇虫梅（心，人）の 各群に增加をみるが，RN.Iは鉤虫拉に增/几，

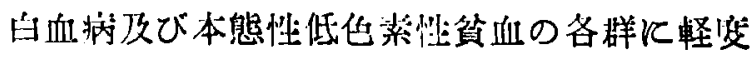
の減少がある。

\section{4）㫮核酸}

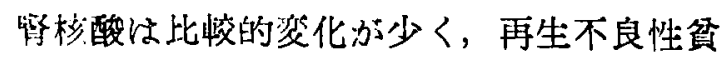
血で DNAの增加, 白血垓及び鉤虫症（犬） 群で RNA の減少をみる，保康人群を基华と してみ机は，更に再生不良性盆血及びバンチ

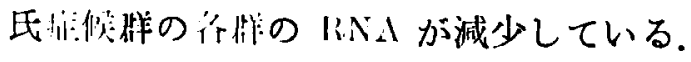




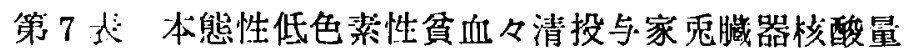

\begin{tabular}{|c|c|c|c|c|c|c|c|c|c|c|c|}
\hline 家 & 鬼 & 番 & 1101 & 1102 & 1103 & 1104 & 1105 & 1106 & 1107 & 1108 & 1109 \\
\hline 患 & 老 & 氏 & 岩 井 & 池 田 & 岩 井 & 直 原 & 直 原 & 佐 藤 & 平 网 & 吉 井 & 藤 原 \\
\hline 注 & 射 & 回 & 1 & 5 & 7 & 7 & 7 & 7 & 7 & 7 & 7 \\
\hline 操 & 作 & 期 & 1 & 5 & 7 & 7 & 7 & 7 & 7 & 7 & 7 \\
\hline \multicolumn{3}{|c|}{ 赤血球最大增珹制 } & -18.6 & -16.1 & -27.0 & -25.4 & -14.1 & +19.8 & -34.8 & -17.7 & -22.5 \\
\hline \multirow{4}{*}{$\begin{array}{l}\text { 骨 } \\
\text { 嘴 } \\
\text { 校 } \\
\text { 酸 }\end{array}$} & \multicolumn{2}{|c|}{ DNA } & 69.3 & 142.1 & 109.4 & 126.2 & 69.1 & 103.0 & 56.8 & 42.4 & 55.2 \\
\hline & \multicolumn{2}{|c|}{ RNA } & 39.2 & 69.1 & 67.8 & 67.8 & 39.5 & 55.4 & 48.2 & 38.3 & 54.3 \\
\hline & \multicolumn{2}{|c|}{ NA } & 108.5 & 211.2 & 177.2 & 194.0 & 108.6 & 158.4 & 105.0 & 80.7 & 109.5 \\
\hline & \multicolumn{2}{|c|}{$\mathrm{R} / \mathrm{D}$} & 0.57 & 0.49 & 0.62 & 0.54 & 0.57 & 0.54 & 0.85 & 0.91 & 0.98 \\
\hline \multirow{4}{*}{$\begin{array}{l}\text { 䏦 } \\
\text { 惔 } \\
\text { 酸 }\end{array}$} & \multicolumn{2}{|c|}{ DNA } & 33.9 & 37.2 & 44.1 & 28.5 & 21.8 & 35.7 & 41.4 & 28.2 & 40.3 \\
\hline & \multicolumn{2}{|c|}{ RNA } & 107.5 & 83.4 & 92.0 & 112.6 & 132.1 & 114.0 & 55.4 & 117.7 & 88.0 \\
\hline & \multicolumn{2}{|c|}{$\mathbf{N A}$} & 141.4 & 120.6 & 136.1 & 141.1 & 153.9 & 149.7 & 96.8 & 145.9 & 128.3 \\
\hline & \multicolumn{2}{|c|}{ R/D } & 3.17 & 4.46 & 2.08 & 3.95 & 6.06 & 3.14 & 1.34 & 4.17 & 2.18 \\
\hline 脾 & \multicolumn{2}{|c|}{ DNA } & 69.4 & 104.7 & 105.9 & 104.4 & 136.0 & 98.9 & 45.7 & 67.8 & 92.8 \\
\hline \multirow{3}{*}{$\begin{array}{l}\text { 伭 } \\
\text { 酸 }\end{array}$} & \multicolumn{2}{|c|}{ RNA } & 63.1 & 71.5 & 80.8 & 75.2 & 73.3 & 93.7 & 32.6 & 62.2 & 88.0 \\
\hline & \multicolumn{2}{|c|}{ NA } & 132.5 & 176.2 & 186.7 & 179.6 & 209.3 & 192.6 & 78.3 & 130.0 & 180.8 \\
\hline & \multicolumn{2}{|c|}{$\mathrm{R} / \mathrm{D}$} & 0.91 & 0.68 & 0.76 & 0.75 & 0.54 & 0.95 & 0.71 & 0.92 & 0.95 \\
\hline \multirow{2}{*}{ 焣 } & \multicolumn{2}{|c|}{ DNA } & 40.2 & 21.3 & 37.4 & 37.0 & 39.6 & 41.1 & 36.9 & 34.8 & 29.4 \\
\hline & \multicolumn{2}{|c|}{ RNA } & 59.0 & 65.9 & 54.5 & 69.5 & 40.4 & 65.8 & 45.4 & 57.0 & 63.8 \\
\hline \multirow[t]{2}{*}{ 酸 } & \multicolumn{2}{|c|}{$N A$} & 99.2 & 87.2 & 91.9 & 106.5 & 80.0 & 106.9 & 82.3 & 91.8 & 93.2 \\
\hline & \multicolumn{2}{|c|}{$\mathrm{R} / \mathrm{D}$} & 1.47 & 3.23 & 1.47 & 1.88 & 1.02 & 1.60 & 1.23 & 1.64 & 2.17 \\
\hline
\end{tabular}

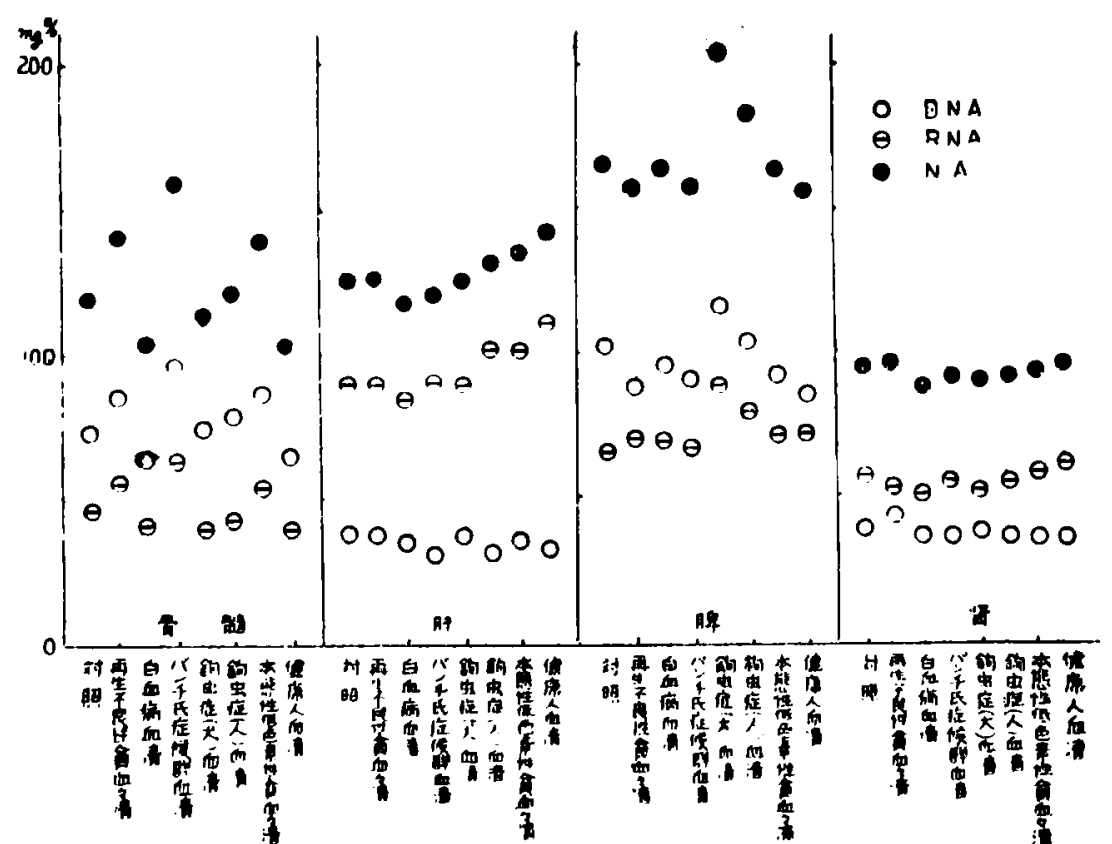

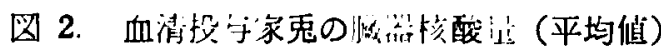

はVirchow の細胞病理 “兴就に取つて代られたが， 其约進展をみせている内 分泌受飞体波病理学の思 想が再舆した感がある。

ここに示した諸疾患につ いて血清の影響を検する ことは, 或意味で体液病 理学的の検討とも云えよ 5.しかしながらこの血 清物質はそれによつて疾 满を惹起するるのとる， 或は疾狲による代謝異常 産物とも，更には単に疾 病による應物ではあるが， 疾病の一部の病態或は症

\section{§3. 総括並に考按}

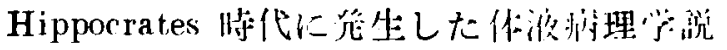

候を惹起するすのとす考えられる。現在まで の研究に於てこの区別が必ずしす判明してい るとは思われない，従って本研究すとの何れ 
第 8 表 健康人血清投与-家兔跲器核酸昌

\begin{tabular}{|c|c|c|c|c|c|c|}
\hline \multicolumn{2}{|c|}{ 家鬼番号 } & 1201 & 1202 & 1203 & 1204 & 1205 \\
\hline \multicolumn{2}{|c|}{ 氏 名 } & 山田 & 難波 & 田村 & 山村 & 田中 \\
\hline \multicolumn{2}{|c|}{ 注 射 回 数 } & 4 & 7 & 7 & 7 & 7 \\
\hline \multicolumn{2}{|c|}{ 操 作 期 間 } & 4 日 & 7 & 7 & 7 & 7 \\
\hline \multicolumn{2}{|c|}{$\begin{array}{l}\text { 赤血球最大 } \\
\text { 增 減 率 }\end{array}$} & -16.1 & -24.4 & +13.8 & +20.1 & -15.8 \\
\hline \multirow{4}{*}{$\begin{array}{l}\text { 骨 } \\
\text { 醚 } \\
\text { 核 } \\
\text { 酸 }\end{array}$} & DNA & 79.2 & 68.4 & 71.3 & 47.3 & 53.4 \\
\hline & RNA & 53.0 & 48.1 & 41.9 & 21.8 & 29.6 \\
\hline & NA & 132.2 & 116.5 & 113.2 & 69.1 & 83.0 \\
\hline & $\mathbf{R} / \mathrm{D}$ & 0.67 & 0.70 & 0.59 & 0.46 & 0.56 \\
\hline \multirow{4}{*}{$\begin{array}{l}\text { 肝 } \\
\text { 核 } \\
\text { 醉 }\end{array}$} & DNA & 37.0 & 28.8 & 39.3 & 28.6 & 24.6 \\
\hline & RNA & 95.8 & 126.8 & 106.8 & 121.4 & 100.4 \\
\hline & N/A & 132.8 & 155.6 & 146.1 & 150.0 & 125.0 \\
\hline & RD & 3.86 & 4.40 & 3.68 & 4.25 & 4.09 \\
\hline \multirow{4}{*}{$\begin{array}{l}\text { 膘 } \\
\text { 核 } \\
\text { 酸 }\end{array}$} & DNA & 82.3 & 91.0 & 81.2 & 75.4 & 96.2 \\
\hline & RNA & 72.9 & 68.8 & 52.0 & 67.1 & 94.8 \\
\hline & NA & 155.2 & 159.8 & 133.2 & 142.5 & 191.0 \\
\hline & $\mathrm{R} / \mathrm{D}$ & 0.88 & 0.76 & 0.64 & 0.89 & 0.99 \\
\hline \multirow{4}{*}{$\begin{array}{l}\text { 等 } \\
\text { 核 } \\
\text { 酸 }\end{array}$} & DNA & 26.8 & 36.4 & 34.6 & 41.7 & 37.9 \\
\hline & RNA & 59.4 & 69.9 & 58.6 & 63.3 & 53.5 \\
\hline & NA & 86.2 & 106.3 & 93.2 & 105.0 & 91.4 \\
\hline & $\mathbf{R} / \mathbf{D}$ & 2.22 & 1.92 & 1.62 & 1.52 & 1.41 \\
\hline
\end{tabular}

を検討しているかは不明のまま行つたもので ある。

諸種血液疾忠の脑令呀刺漼の核酸星を Davidson 1621，蔽池 ${ }^{37) 391}$ が計測しているが，

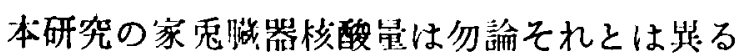
観点から眺められなければならない。

\section{1. 再生不良性艎血々清}

再生不良性盆血は貧血の中でも不治として 取残された最大の城邡で，しかも比較的我国 に多いところからその研究は近年甚だ盛んで ある. 成因については各種の症候性のものも あるが原团不明のものもある。しかも忙惟の 芜義にもある通り予後は多くは不良で「総ゆ る治療に反応せず」不幸の転帰を取るものが 大部分である。

本症の血清物質を検索したものに Francke 176)の Leucotoxin 説があり，それに次で

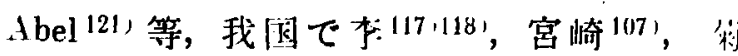

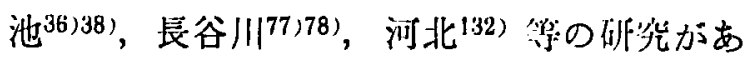

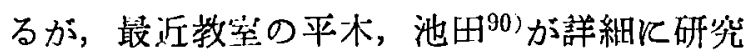
したところによつて約言するならば，患者血 清には家华に筫血を起させる因子があり，ア ルコール，エーテル溶性でその作用には網内 系の能全なことを要すると云うのである，更 に゙教室の骨䯠培養への添加垁験20)91〕よると 血清中の催筫血因子は㨁接骨能淔作用して赤, 白両血球系の增生を抑制し，細胞機能子低下 せしめる。料池 ${ }^{38)}$ 等も in vitro で正常血湤 細胞の形態機能に障碍作用を及任す中毒性物 質の保作を想定している。

さて私の得た成績を眺めると骨能道に於ては 秙惨酸们鄱ともに增加する。しかも対照たる 健康人の場合には減少しているのを考虑すれ ば，この場合の增加は著明である。この成績 は一見甚だ矛盾するものである。即ち本症は 始めて定義ずけた Ehrlich から，骨鹃組織の 荒廃を以て特徵として括り，核酸についての 研究は比輍的少いがそれです菊池 ${ }^{37}$ (39)の化学 的定量, 上村 ${ }^{30)}$ の細胞化学的定量の何れか らみて子骨髄両核酸成分の減少を証明してい る. 又上原 ${ }^{1314)}$ 等によれば呼吸解糖作用が 著しく低下していると云5のであるから，再 生不良抄蚠血患者骨䯣飞於ては代謝機能の低 下゙があることを裹書きし，勿椧細胞增殖が障 碍されていることは想像出来る．以上の事項 は私の成緽と全く相反するものであうて，乙 かも家鬼飞筫血を起すので筫㲹発生機枟は思 者の埸合と全く異るものとも溚えられる。し か乙再生不良性贫血は決して単一な疾病では ない.Bock の模型図によるまでもなく本症 と顆粒球減少症及び血小板減少症との総ゆる 移行型が存在するのであり，更飞本症のみる Roads and Miller221)，森用(111)管に上り種々 の满犁に分けられている。平木教授 ${ }^{8993)}$ とよ る最新の分類を慈飞举げると，骨髄障碍状態 より i）骨髄内血球㧕留型，ii）成熟抑制型， iii）生成障碍棐，iv）混合型及びv）沉骨䯕 瘵型に分けられ，私の症例でも表1飞病型を 附記している。即ち再生不良性負血でる必ず

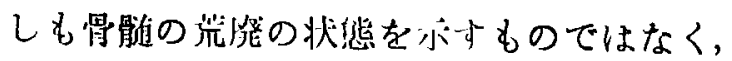

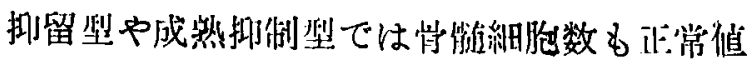


を示するのあり，呼吸解糖能も正常に近い侐 を取るすのである，実験例では核酸の增加を みる故細胞增殖などもありそうなものである の飞貧血を起している。このことから私は骨

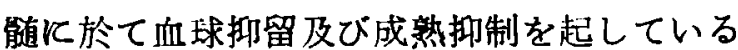
すのと想像与る．抑留作用により細胞が充满 していれば，その含有核酸量は增加する管で あるし，或は代謝又は新生機能る亢進してい るかる知れない，ただその新生細胞が抑留さ れ，或は代謝が将的飞行われて成熟が不充分 でdysfunction の状態炕あるも考え得る. 比 較的長期間注射を行つた0610例では骨艏核酸 は大体正常值となつて拈りこのことから本 症では毒性物質により骨䯣に血球抑留 $\rightarrow$ 成熟 障碍 $\rightarrow$ 生成不全の順に障碍が起り，遂には荒

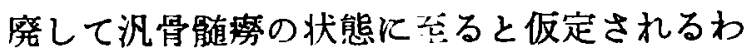
けである. Heilmever u. Plöttner ${ }^{183)}$ 其他の 研究より，本症では高度の貧血飞各拘わらず 血清鉄の增加することは定説となつて抲り， 鉄利用又は動員障碍が考えられるが，同様に 核酸の利用不全す考えられよう。

肝䑏核酸量は大体正常であるが，健康人血 清注射の際と対比すれぼDNAの增加, RNA の隇少をみる。再生不良性負血の際の肝機能 は Rhoads，長谷川7778，等によれば障碍され るものもあるが决定的の断を下し得ない様で ある。しかし私の成續から血消物梊が肺機能

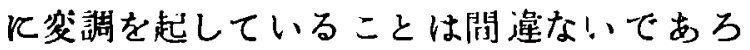
3 .

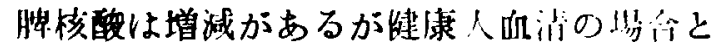
同様であつて，纱は人した影沙はないもので

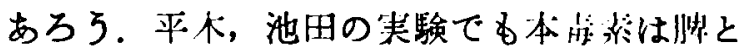
関係のないことになつている。

䇾は DNA の增加と RNA の減少とをみ， 之は他の血消注射の剒合飞比へてて最も著明な 変化である。この関係は前記肝の倠合と同保

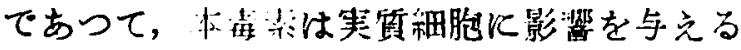
すのと考えられる。

以上の所見は病型により特異な校化はなく， 従つて前記の各病型の积行性もこの辺からあ 無理なく説明し得る。

\section{2. 白血病血清}

本症の際には極く稀飞赤们!!增多症を起す 例はあるが，殆んどの例は早晚貧血に陥る。 この貧血は白血球系造血装置飞より赤血球系 造血装置が压迫されて起るすのと解せられて いるが，血球破壊機能の促進も考光られてお り，更に進んでは貫血があつても赤血病の様 相を呈するすの，再生不良性筫血病像を呈す るもの等㮔々であつて，その間には移行型も ある．是の如くみれば白血病と負血諸疾患と の関係は紙一重とも云える。

向血病の本態関しては古来多くの説があ

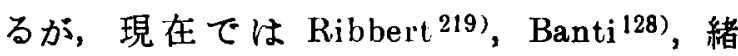
方25126)等によつて唱えられた腫愓説が大勢を 制している，本症を蚛性喱瘍と見做すならば 肉腫及び癌は同系列に属するすのであるが， 肉腫については風24，長谷川年)の毒素証明あ り，癌毒素は䄆覀液質，特飞貧血を起す要因 として、.Leyden 201)，Marchand ${ }^{205}$ ) 等により 初めて唱えられ其後多数の支持者を得ている。 最近中川73)等は癌毒素の精製を行い RNA K 属するものとしているのは興味深い。

さて本症血清中の毒素次つては李 120)が 赤血球数減少，白血球数增加の因子を証明し

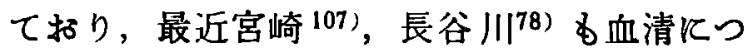
いて検しているが，古く海外では Wearn ${ }^{239}$ ， Hirschmann ${ }^{187)}$, Miller ${ }^{208)}$, Heinle ${ }^{185)}$, Turner and Miller ${ }^{236)}$, Erf ${ }^{170)}$, Foster and Miller 175), Loenhartsberger ${ }^{2021}$, Olira2(5), 染

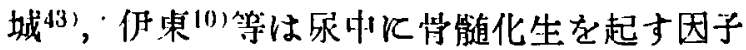
を証明しているが，粥川(日月73) 血清中にこの 则子を証明している。

骨髄核酸量は淢少しているが，健康人血消 注射例に比へると大差はない。しかも血球計

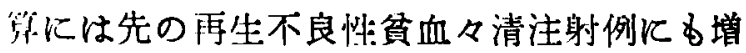

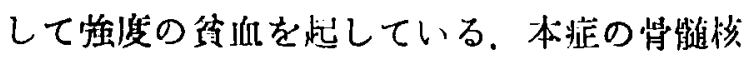
酸について Davidion，約池等によれば，総 㤥酸㫫，特に DNA の增加を認めているが， 尚髄有柆縕胞数の增加がある以上当然である 5。本血清注射で硁康人血清注射の際よりも 一屏赫血球の減少しているここより，その代 謝も dysfunction の形を取つているすのと思 われる。 
肝は両核酸とも減少するが対照健康人に比

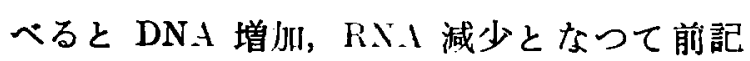
再生不良性貧血の場合と同様であり，肝代㴬 異常を想像する。

脶では健康人血清注射の場合に比べて RNA は殆んど裔㽖なく，DNA が增加する。 本脾内では滤胞内の細胞新生が盛な為である 3 .

觜核酸は健康人対照に此べて RNAが減少 する，聅質障碍の為と考える。

白血病の種類による区別は病例が少いため か確認出来なかつた。

\section{3. パン氏症候群血清}

バンチ氏症候群は䐑疾患中代表的なるので あるが，袜脿機能が全く解明されていないと 共に本症の榆廓は明でない. Bantij ${ }^{12 T}$ が 1894 年始めて Splenomegalie mit Lebercirrhose として発表してから本症候群に対する議論は 甚だ盛んであるが，近年は我国《於て友田711 一門が脾性中毒症として広沉な研究を進めて いると其に，鈴木等の抗原抗体反忍説に更に hypersplenism の概念及び門㟲位艺進等の各 種学説が錯綜している.

本症が毒性に発生することは既に Banti も想像していたところであつて，其後飯域ら，

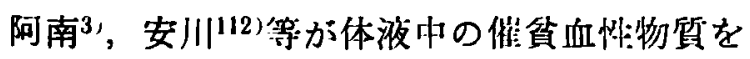
追求しているが，友田門下゙でも古森 ${ }^{19}$ ，陳 ${ }^{(8)}$ ，

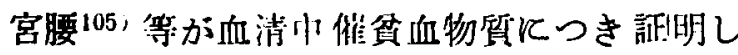
毒素を抽出している。涽胡等は本症脾より $\mathrm{MgHPO}_{4}$ や $\mathrm{CaHPO}_{4}$ の椂な鹪単な物質を批 忚し，䒔が本症毒素であると公う。

血清注射飞よつて家鬼飞起る盆血は白血狱

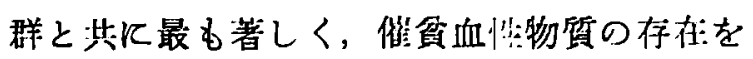
肯定せしめるが，骨髄核酸は非常に增加して

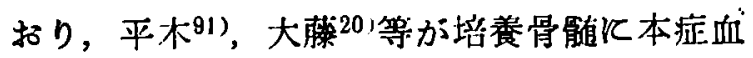
清を添加した場合，即ち毒素の直接作用によ ると細胞增生並にその機能を高度に障碍する ことを認め，上村 ${ }^{30}$ )が患者骨髄穿刺液で DNA の滅少，RN入の増加を観察したのとは いささか趣を異にする。杉野58), 宮腰(06), 辻 村69)70）本症腗䑏毒投与の場合骨髄造血機 能の㧕制，殊飞赤血球の增生㫫に成熟障碍が。
ありビタミンC 及びクルタチオン莗が低下す ることよりる骨骫機能が低下寸ると云了，従 つてこの場合の核酸の態度は再生不良性貧血 に师て述へた粎に，一㮔の dy'sfunction で説 明されると考元る。

肝は雨核酸とも飞減少する。本症に於ては 肝障碍から肚硬変を起するのであり, 䓯素に よつても肝硬変類似の病変を起し得ることが 古森, 永野50)飞よつて証明されている。肝障. 碍によつて含有核酸暴の減少することは周知 のところであつて，本奏験の場合す機能障碍 の一面を示すすのであろ5。

䏚吽毒があると寸れば肔と並んで蚶の態度 も考愿に入れるべきであるが，蜰性毒の腙に 対する影響は杉野58によれば充血及び線維の 增加である. 核酸嘼はDNAの增加及び RNA の減少が軽度にみられるのみで，意外飞変化 は少い。

呰には雨核酸成分の減少を認め，朋と同様 勧诈障得を現わするのと考学られる。

\section{4. 鴒虫性筫血々清}

鈎虫症の最も著明な症状は貧血であるが， その成因に関しては未だ定説がなく，主な説 としては次の三つが举げられる. 即ち虫体の 咬着による出吹を主因とする失血吽貧血説, 虫作寄生汇よる腸管機能障碍の起す栄養障碍 悱盆血説及び虫体或はその新陳代謝産物中毒 による中毒性畕血説がそれである．現在のと ころ本症関する教察北仙，平木雨教授及び その門下の広沉且精密な追究により，中毒説 が学会の大勢を制している．本血清中の催會 血性物質については溶血毒説は整く指き，骨 䯣障碍物質を証明したものに山田114)，村 田 ${ }^{109}$ ，小森 ${ }^{48}$ ，浅越 ${ }^{2}$ ，宮崎 ${ }^{107)}$ 及び教室笠 原 ${ }^{28)}$ があり更飞佐久間51)，平木88992)，米谷 ${ }^{96)}$ の研究を併せて北山，平本の棕括したところ によれば，本儌貧血性物質は虫体に含まれる Ankylon A, B の両者があり, 前者はアルコ ール，エーテル不溶で後者は可溶性である。

Aは作用弱くさが倠貧血的飞働く為には脾 の作用を必要とし，Bは肝で賦活されて Ankylonひとなり，兰が血清中を流れている 
あので，かくなつて始めて骨䯙に作用する様 になる。而して雨者とる網内系が健仨であつ て始めてその作用を発揮する．更に本虫表素

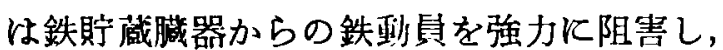
この事が又本症筫血発生の強力な因子になる という，尖験では鈳虫患者及び鉤虫犬何机の 血清でも大休同様の貧血を起すが，比較的そ の程!度は弱い。

骨髄核酸は践康人血清注射に比べてDNA が増加し， RNA は比較的に変㡖が少い. 即 ち RNA からは比較的新陳代謝が少く，DNA 增加は細胞增玑により招来したるのと考えら

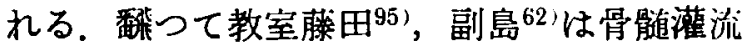
実䮖より，血清毒素は直接骨髄飞作用して動 脈系を收縮し，血球を骨䯑道中広大な容積を有 する静脈洞に抑留することを明にし，更に藤 井86 はその際骨髄内血流が遅延することを証 明している，他方大藤 ${ }^{20}$ は培養骨骮有に本症血 清を添加しても，健康人血清添加の際と差異 のないことを証明して招り，彼是考元併せる と本症のAnkylon〔飞より骨髄内血流の遅 延, 血球抑留の状態が長時間持続する為に, 骨髄実質飞二次的飞造血障碍が来ると思われ

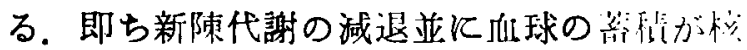
酸に反映したものであろ 5 .

鈎虫奇生により肝機能の障碍されることは 多くの先人の業蹟 11751156 （66) に徽しても明で ある。しかも肝は倠筫血性物質の賦活江蚠血 発生上重要な役㓶をするのであるが，本类䮖 の場合注射した血清川に含まれるものは主と して Ankylon“であり，肺はこの埸合にし た役割を持たないとも龵えられる，定壮の成

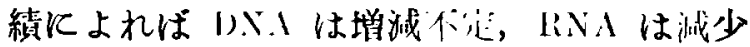
している。この変化は恐らく毒性物行による 肝障碍の反映である5.

胜では山核酸成分ともに著明な增加をみ る。これは㳀器エキス及び血榈注射を通じて

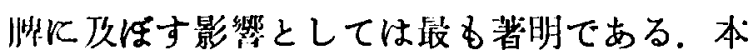

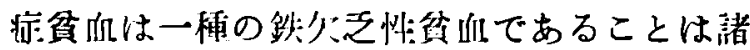
家3452,72,194102，によつて恝められているが，

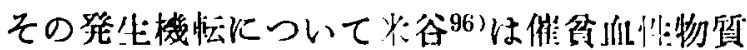

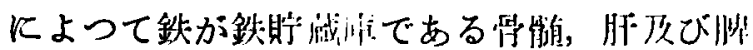

の網内系に食喰，扸留され，その為飞鉄の利 用障碍の来ることを証明しているが，臌器非 へミン鉄第亚分劃は現在のところ核酸に附着 していると云われているので，この核酸增量 と鉄代謝恋調との関係は甚だ興味ある問題と 思われる。

惂の核酸量はDNA 稍々增加の傾向あり， RNA は減少する，本症飞於ては浮苦病の名 の通り浮腫を示するのがるが，その成因に は循環器系, 血清蛋白及び無機堛の変調とと もに組織性障碍が挙げられ，堅の態度が重要 な因子となつている41）。この核酸変動も実質 怡，間質州障碍を反映するものであろう。

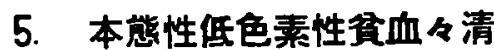

次態吽:低色素性貧血飞恃発性の鉄欠乏性 貧血である萎黄病，胃液欠乏性萎黄責血及び 後者飞属する Plummer-Vinson's syndrome が含まれる，本症に鉄が有効なことは古くか ら知られていたが, Schur ${ }^{226)}$, Heilmeyer ${ }^{183)}$. IIore $\mathrm{e}^{211)}$ 等により血清鉄量の減少が発見され 本症が鉄欠そにより起ることは明白となつた。 而ると鉄欠之の原因は未だに解明されていな い. 本症と胃所見との関係が注目され胃液酸 度(1413141，胃排泄時間2331，胃粘膜の状態 157)213) との関係が検討されているが，鼠近中尾 ${ }^{72)}$ も本症成因飞胃腸粘膜の病変飞よる鉄吸收障 碍を述べている，古く Kaznelson ${ }^{192}$ )等は腸管 内瑇素を想定していたが，学会の大勢は催負

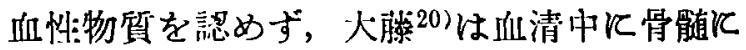
対して直接作朋を及ぼすすのはないと云う。

向清を家，に注射したところでは図1の様

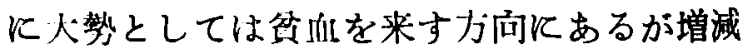

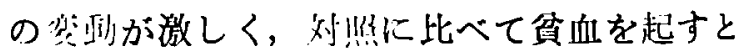
は決定し難い。

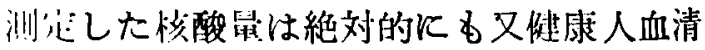
例に比べても決して舆変䣦ではない，図 2 飞 見られる様に㫮は先ず変軼がないが，肝及び 纱は㹩浚ながら增減が泪められ，この両者は 鉄代謝との関係から影響があるかとも考兄ら れる。しかし最も忿化のあるのは骨髄であつ て，涧核酸の增加はバンチ氏症候群及び再生

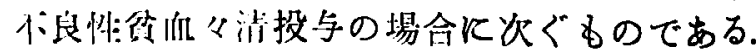


このことから血清中に所謂催貧血性物質は存 在しないかも知れないが何等かの異常物質が あり，それが骨髄に作用することは想像に難 くない，同じく骨髄核酸の增加するバンチ氏 症候群は鉄欠乏性で本症に通ずるところがあ るが，再生不良性貧血は然らず，共通すると は云い難い，何れにしても他の原因と呼応し て鉄代謝変調の原因となるるのか，或は代謝 変調産物であるかは判明しないが，或種の物 質の存在を認めて差支えないと考兑る。

\section{6. 健康人血清}

本例は対照実験として行つたのであるが， 臟器核酸量は無処置対照に比べて相当の変動 がある。寨験に使用した血清量は人間に換算. すれば相当多㫣であり，含まれる蛋白質其他 の成分による影響から相当の翋㡖，起り得る ことは当然予測される．更に巽種血清注射は アレルギー性反态をる惹起せしめ得るのでこ の変化を生じたものであろう。

骨髄の核酸はすべて減少している。これが 蛋白代謝の減退, 細胞分裂の減衰の現われと すれば輸液上考慮を要することであろう。す ヘてての貧血を通じて万能的で最も有効な方法 として輸血が盛飞用いられているが，との際 の血清又は血焚は骨髄障碍性の面があるので はないかと思われる。事奉外科的方面で盛に

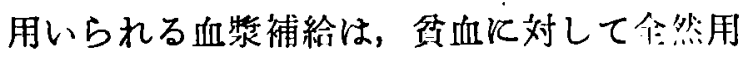
いられていない様である。

尤子輸液上蛋白質補給の面は们液生成礎材 補給の意味で意義のあることで，胙 RN.1の 增加も之を糔書しているから一概飞障碍面の みがあるとは云えない，脏 INA の增田は他 に比へて最も著明であつて。この桨から将的

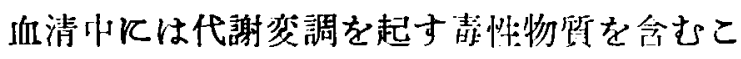

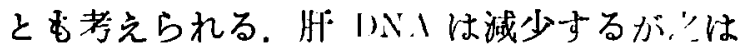
すべてを通じて胃られることである。

脾はリンパ球生成と血球処理を行う他に血 液成分の貯蔵, 放出を行了故, その棈成々分 は非常に不安定であつて一概には核酸の增減 を論じられないと考える，肉腿的にみても血 涯注射の際は蜰はすへて增火し，特に鈎虫犬 血清注射例のものは著明であった，蛜康人低
清例の DNA は他に比べ最も減少し，RNAは 增加しているが他に比へて程度は少い。

督の核酸は一艋に変動が少いが，すべて減 少の傾问にある。代謝終産物の処理場として 㭥討したわけであるが，やはり血液関係蔵器 でないところから糸唒は少い。

以上種々㧈清注入に際しての核酸の態度を 䜊じたが，剖編に述べた定量上の䛊差以外に， そは毒素のみの注入罢験ではなく，おくまで 血清往入の際の成績であるので，他成分，殊 飞血清蛋白質等の影響。考虑に入れなければ ならないし，又核酸量の增減の生物学的意義 についても現在の段階ではやっと序のロに入 つたばかりであり，何れにしても本研究は現 在まで全く未知の領域に足を踏入れたもので， 血清作用, 血液学, 血清毒の研究考察のみな らす，逆に核酸の持つ生物学的意義について る基礎的資料となり得ると考える。

\section{§4. 結論}

各種血液疾患々者血清及び対照健康人血清 を家鬼に静注し，その骨髄，肝，腺及び等核 酸晕を測定検討したところ，次の成績を得 た.

1）。㯬康人血清注射の際は骨䯚核酸及び肔，

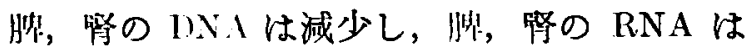
㹩陵に，肝の RNA は相当飞增加する。

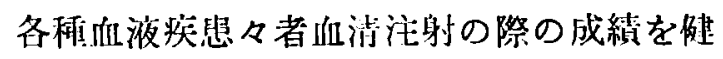
康人任清注射の際と比洨すれば,

2）阵生不良性分抓々清注射では骨䯠核酸 の洒成们は著明に，胙队び紫の DNA は相当 增玑し，朋〕び紫の RNaは相当減少する。 泤核酸は人した夜抄がない。

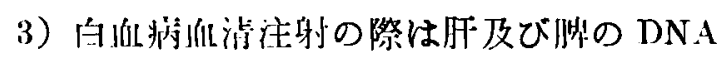

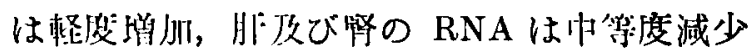
するが，其他は火した奖化がない。

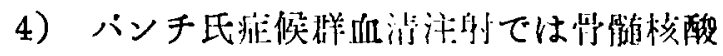

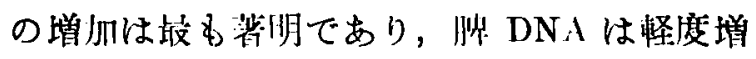

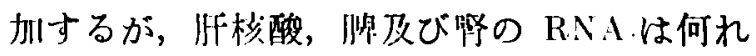
る怪股減少与る。

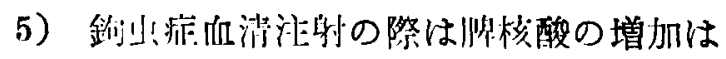

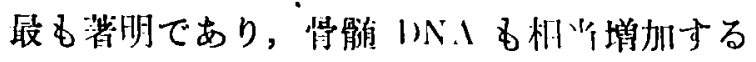


が，肝及び留のRNAは何れも減少する。

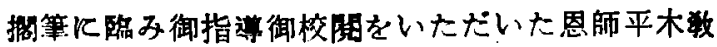

6）本態性低色素性貧血々清注射に際して 授に南心より感謝の意を表する。 は骨䯠㤥酸雨成分の著明な增加があるが，其

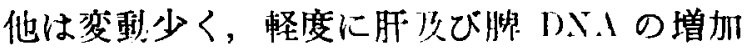
と，肝RNAの減少とをみるのみである。

有論文の要旨は昭和30年 4 月第17回日本血液学会 総会に於て発表した。

（文 献 後 揭）

Dept. of Internal Medicine, Okayama University Medical School.

(Director Prof. Dr. K. Hiraki)

Influences of Organ Extracts as well as Serum of Blood Disease

Patient on the Nucleic Acid Metabolism of a Rabbit.

2nd Report : Influences of Serum of Patients of Blood Disease

on the Nucleic Acid Quantity of Rabbit's Organs

By

Tatsuji NAMBA

By. intravenous injection of serum of patients of blood disorder as well as control serum of healthy men, observed the nucleic acid appearing in its bone-marrow, liver, spleen, and kidney, which proved as:

1) In rase healthy men is serum has been injected, bone-marrow nucleic acid and DNA in, liver, spleen, and kidney indicite ! decrease; while RNA both in spleen and kidney increases slightly: and that of liver doess so protty much.

If those results obtained will be put under comprapison with those obtained under the use of healthy men is serum :

2) Incler the administation of serum of hypoplastic anemia, bone-marrow nucleic acid increases in a marked degree, liver as well as kidney I)NA do so in a moderate degree; R.NA of liver and kidney decrease whin's. Is lo spleen nucleic acid, no marked change occurs.

3) If the serum of lenkemia is injected, a slight increase takes place to liver and spleen DNA, while liver and kidnel R.I show an abatement quite: but as to the rest, no great changes appear.

4) When strum of Banti's sindrome has been injected, the increase of hoth the bonemarrow nurleic acid prove most randid: thung the spleen DNA increases, liver nucleic acid as well as RNit of spleen and kidney show a slight derreaste respertively.

5) On occasion serum of hookworm inemia has been injected, spleen nucleic acid proves a marked increase; bone-marrow INA increases wreall, but RNA in liver and kidney decreases.

6) When serum of essential hypochromic anemia is injected, a remarkable increase in the bone-marrow nucleic arid happens; hut is 10 the rest, small change occurs, only a slight increase of liver and spleen INA, along with a decrease of liver RNA. 